\title{
Identification and Comparative Study of Invitro Antioxidant Potential of Fractionated Hydroalcoholic Extract of Phyllanthus Niruri Linn
}

\author{
Gayathri R, and Manju S.L*
}

\section{ABSTRACT}

It is apparent that varieties of plants have the potential to show numerous preventive and therapeutic activities that may be relevant to the treatment of disorders caused by oxidative stress and free radicals. A variety of herbal extracts and their phyto components have been demonstrated to exert antioxidant activities, either by directly stimulating antioxidant response genes or by potentiating the bodies` own natural antioxidant defense mechanism. This study reported the high-performance liquid chromatography, invitro antioxidant activity, measurement of total phenolic and flavonoid contents of various solvent extracts of whole plant of Phyllanthus niruri in order to find possible treatment of disorders caused by oxidative stress such as neurodegenerative diseases. Results obtained revealed that, ethyl acetate fractions of $P$. niruri whole plants possess high flavonoid and polyphenolic compounds which ultimately leads to the potent antioxidant activity than other polar and nonpolar solvent fractions. Thus, this study suggests that, these fractions can be used as a potent source of natural antioxidant there by it can be used for the further investigation for the treatment of neurodegenerative diseases and other free radical induced pathological conditions.

Keywords: Phyllanthus niruri, HPTLC, ethyl acetate, flavonoid, polyphenol, antioxidant, neurodegenerative disease

Published Online: January 20,2020

DOI : 10.24018/2020.1.1.2

Gayathri R.

Department of Chemistry

School of Advanced Sciences

VIT, Vellore-632014

Tamilnadu, India

(email: r.gayathri08@gmail.com)

\section{Manju S.L.*}

Department of Chemistry

School of Advanced Sciences

VIT, Vellore-632014

Tamilnadu, India.

(e-mail: slmanju@vit.ac.in )

*Corresponding Author

\section{INTRODUCTION}

Oxidative stress has been implicated in various pathological conditions including cardiovascular diseases, cancer and age-related disorders1. Medicinal plants containing variety of bioactive substances which are of considerable use against various diseases. The demand for natural food ingredients has resulted in extensive research on naturally occurring antioxidants which can neutralize highly reactive free radicals. In recent years, much attention has been devoted to natural antioxidant and their association with health benefits. The plant extracts or their metabolites have act as antioxidants in phytotherapeutic medicines to protect and treat various diseases for centuries related to oxidative stress and free radicals2. It produces various antioxidative compounds to counteract reactive oxygen species (ROS) in order to survive. ROS, which include free radicals such as superoxide anion radicals $\left(\mathrm{O}_{2}-\right)$, hydroxyl radicals $(\mathrm{OH})$ and non-free-radical species such as $\mathrm{H}_{2} \mathrm{O}_{2}$ and singlet oxygen $\left(\mathrm{O}_{2}\right)$, are various forms of activated oxygen. The antioxidant enzymes and free radical scavengers may provide a defensive mechanism against the deleterious actions of ROS. Free radicals generated in the body can be removed by body's own natural antioxidant defense e.g. glutathione, catalase etc. However, endogenous antioxidant defences are not completely efficient. Therefore, dietary antioxidants are essential to lower the overall effect of antioxidant stress due to excessive free radicals occurring in our system. Significant antioxidant properties have been recorded with phytochemicals that are essential for the decrease the incidence of many diseases. Therefore, the evaluation of antioxidant activity of various plant extracts is considered as an important step in the identification of their ability to scavenge the free radicals3. Phyllanthus niruri which belongs to the Euphorbiaceae family is also known as kidney stone crusher or seed-under-leaf and can be found in the tropical regions of Asia and America. P. niruri is a chief plant in the Ayurvedic tradition to treat pathological conditions of stomach, genitourinary system, liver, kidney and spleen. Recent studies have also revealed antidiabetic and antioxidant properties of this herbal extract both in vivo and in vitro4. The various extracts of the plant also proved to act as antiviral and antibacterial agent. Indigenously this plant is used for menstrual and other gynaecological problems. Many active phytochemicals such as flavonoids, alkaloids, terpenoids, lignin, polyphenols, tannins, coumarins and saponins have been documented from various parts of P. niruri. Extracts of this herb have been proven to have therapeutic effects in many preclinical studies5. Many crude plants found having antioxidant properties and among the compounds phenolic and flavonoid attracted as noteworthy choice for being used as antioxidants6. There are reports which indicate that P. niruri can block calcium oxalate crystals and stone formation in the kidney, ureter, and urinary bladder. A dual cholinesterase inhibitory-guided fractionation of $\mathrm{P}$. niruri leaves afforded isocorilagin, a bioactive tannin possessing 
good inhibitory activities against acetylcholinesterase (AChE) and butyryl cholinesterase (BChE) which are playing potential role in Alzheimer's disease pathogenesis7.

The aim of the present study is to characterize the major chemical groups by high performance liquid chromatography (HPLC) of fractions from hydroalcoholic extract of whole plants of P. niruri (HAPN) and evaluate the different free radical scavenging activities including the 1,1-diphenyl picryl hydrazyl (DPPH), hydroxyl radical and their reducing power capacity of fractions from HAPN.

\section{PROCEDURE}

\section{A. Plant material and preparation of plant extract}

Fresh whole plant of P.niruri (PN) were collected from farm fields around Erode and Namakkal district, Tamilnadu, India and authenticated by pharmacognosy division of SKM siddha and ayurvedha company(India) pvt limited. After authentication, the fresh healthy whole plant P.niruri was dried properly in shade for 3 weeks, segregated, pulverized by a mechanical grinder and passed through a 40-mesh sieve. The powdered plant materials were stored in an airtight container and used for further studies. The powdered drug was defatted with n-Hexane using Soxhlet apparatus. The extraction was performed using maceration with $70 \%$ ethanol $(1: 5 \mathrm{w} / \mathrm{v})$ for 7 days with occasional shaking to obtain hydroalcoholic extract of PN (HAPN). The liquid extract was evaporated using a rotary evaporator at $40^{\circ} \mathrm{C}$ and until a thick extract was formed. The residue was then weighed and stored in a sealed container. The residue was suspended in water and partitioned successively with petroleum ether, ethyl acetate and n-butanol (a total of two aliquots of $100 \mathrm{ml}$ each) 8. The percentage yield of successive solvent extractive values for Phyllanthus niruri was calculated. The residue was stored in airtight container for further studies. The final residue thus obtained from various fractions were then subjected to HPTLC analysis and assessment of antioxidant activity.

\section{B. Phytochemical screening}

Phytochemical screening of the crude extract and fractions was carried out in accordance with standard test procedures described by Evans9.

\section{Determination of phenolic content}

The total phenol content was determined by adding $0.5 \mathrm{ml}$ of the aqueous extract to $2.5 \mathrm{ml}, 10 \%$ Folin-Ciocalteau's reagent $(\mathrm{v} / \mathrm{v})$ and $2.0 \mathrm{ml}$ of $7.0 \%$ sodium carbonate. The reaction mixture was incubated at $45 \mathrm{oC}$ for $40 \mathrm{~min}$, and the absorbance was measured at $765 \mathrm{~nm}$ in the spectrophotometer. The mean of three readings was used and the total phenol content was expressed as milligrams of gallic acid equivalents/g extract 10 .

\section{Determination of Flavonoid content}

Total flavonoid content was measured by the aluminium chloride colorimetric assay 11. An aliquot $(1 \mathrm{ml})$ of extracts or standard solutions of quercetin $(20,40,60,80$ and 100 $\mu \mathrm{g} / \mathrm{ml}$ ) was added to a $10 \mathrm{ml}$ volumetric flask containing 4 $\mathrm{ml}$ of distilled water. To the flask, $0.30 \mathrm{ml}$ of $5 \% \mathrm{NaNO}_{2}$ was added and after $5 \mathrm{~min}, 0.3 \mathrm{ml}$ of $10 \% \mathrm{AlCl}_{3}$ was added. After $5 \mathrm{~min}, 2 \mathrm{ml}$ of $1 \mathrm{M} \mathrm{NaOH}$ was added and the volume was made up to $10 \mathrm{ml}$ with distilled water. The solution was mixed and absorbance was measured against the blank at $510 \mathrm{~nm}$. The total flavonoid content was expressed as mg quercetin equivalents $(\mathrm{QE})$

\section{TABLE 1: PERCENTAGE YIELD OF EXTRACT OBTAINED BY MACERATION}

\begin{tabular}{llll}
\hline S.No & Extracts & Colour & $\begin{array}{l}\text { Yield \% } \\
\text { (W/W) }\end{array}$ \\
\hline \hline 1. & Hexane & Dark Green & 22.30 \\
2. & Hydroalcoholic & Dark brown & 40.12 \\
\multicolumn{4}{l}{ Fractions from hydroalcoholic extract } \\
a. & Petroleum ether & Brown & \\
b. & Ethyl acetate & Light Brown & 20.65 \\
c. & n-butanol & Light Brown & 14.15 \\
d. & Water & Brown & 15.95 \\
\hline
\end{tabular}

\section{E. HPTLC analysis for fractions}

Test solutions $10 \mu \mathrm{l}$ and $5 \mu \mathrm{l}$ of standard solution was loaded as $6 \mathrm{~mm}$ band length positioned $10 \mathrm{~mm}$ from the bottom of the plate, using an automated TLC applicator Camag Linomat 5 instrument with inert gas flow providing delivery from the syringe at a speed of $150 \mathrm{nl} / \mathrm{s}$. Each TLC plate was developed to a height of about $80 \mathrm{~mm}$ with a mobile phase of toluene: ethyl acetate: formic acid: methanol (3:6:1.6:0.4 v/v/v/v) under laboratory conditions $(60 \mathrm{oC})$. The plate was kept in Twin Trough Chamber $10 \times 10 \mathrm{~cm}$ and captured the images at white light, UV $254 \mathrm{~nm}$. Finally, the plate was fixed in a CAMAG TLC Scanner 3 was used to densitometrically to quantify the bands using WIN CATS software (Version $4 \mathrm{X}$ ). The scanner operating parameters were: (Mode: absorption / remission; Slit dimension; 6.00 x $0.45 \mathrm{~mm}$; scanning rate: $20 \mathrm{~mm} / \mathrm{s}$ and monochromator band width: $20 \mathrm{~nm}$ at an optimized wavelength 254, $366 \mathrm{~nm}$ and in visible range) The peak table, peak display and peak densitogram were noted. The obtained results were compared with standard quercetin, rutin and gallic acid.

\begin{tabular}{|c|c|c|c|c|c|c|}
\hline $\begin{array}{l}\text { S.N } \\
\text { o }\end{array}$ & $\begin{array}{l}\text { Fractio } \\
\text { n }\end{array}$ & $\begin{array}{l}\text { Hydroalco } \\
\text { holic } \\
\text { extract }\end{array}$ & $\begin{array}{l}\text { Petrole } \\
\text { um } \\
\text { ether }\end{array}$ & $\begin{array}{l}\text { Ethy } \\
\text { l } \\
\text { aceta } \\
\text { te }\end{array}$ & $\begin{array}{l}\text { n- } \\
\text { Buta } \\
\text { nol }\end{array}$ & $\begin{array}{l}\text { Aqueo } \\
\text { us }\end{array}$ \\
\hline 1. & $\begin{array}{l}\text { Total } \\
\text { phenolic } \\
\text { content } \\
\text { (mgGA } \\
\text { E/g) } \\
( \pm \text { SEM) } \\
\text { Total }\end{array}$ & $70.36 \pm 0.52$ & $\begin{array}{l}20.09 \pm \\
0.01\end{array}$ & $\begin{array}{l}86.48 \\
\pm \\
0.28\end{array}$ & $\begin{array}{l}69.13 \\
\pm 0.02\end{array}$ & $\begin{array}{l}36.48 \pm \\
0.28\end{array}$ \\
\hline 2. & $\begin{array}{l}\text { flavonoi } \\
\mathrm{d} \\
\text { content } \\
\mathrm{mg} \\
\mathrm{QE} / \mathrm{g}\end{array}$ & $58.18 \pm 1.07$ & $\begin{array}{l}10.78 \\
\pm 0.56\end{array}$ & $\begin{array}{l}73.12 \\
\pm \\
1.07\end{array}$ & $\begin{array}{l}52.65 \\
\pm 0.23\end{array}$ & $\begin{array}{l}43.52 \pm \\
0.58\end{array}$ \\
\hline
\end{tabular}


TABLE 2: PHYTOCHEMICAL SCREENING

\begin{tabular}{ccccccc}
\hline $\begin{array}{c}\text { S.N } \\
\text { o. }\end{array}$ & Test & Hexane & Ethanol 70\% & $\begin{array}{c}\text { Ethyl } \\
\text { acetate }\end{array}$ & $\begin{array}{c}\mathrm{n}- \\
\text { butanol }\end{array}$ & Water \\
\hline \hline 1. & Alkaloids & - & + & + & + & - \\
2. & Corbohydrates & - & + & + & + & - \\
3. & Glycosides & - & - & + & - & + \\
4. & Terpenoids & - & - & - & - & - \\
5. & Proteins & - & + & + & + & + \\
6. & Amino acids & - & + & + & + & + \\
7. & Steroids & + & - & - & + & - \\
8. & Flavonoids & - & + & + & + & + \\
9. & Phenols & - & - & + & - & - \\
10. & Tannins & - & - & + & - & - \\
11. & Quinones & - & - & - & - & - \\
12 & Anthraquinones & - & - & - & - & - \\
13 & Saponins & + & - & - & - & - \\
\hline
\end{tabular}

TABLE 4: HPTLC PEAK TABLE FOR HAPN

\begin{tabular}{lllllllllll}
\hline Peak & $\begin{array}{l}\text { Start } \\
\text { Rf }\end{array}$ & $\begin{array}{l}\text { Start } \\
\text { Height }\end{array}$ & $\begin{array}{l}\text { Max } \\
\text { Rf }\end{array}$ & $\begin{array}{l}\text { Max } \\
\text { height }\end{array}$ & $\begin{array}{l}\text { Max } \\
\text { \% }\end{array}$ & $\begin{array}{l}\text { End } \\
\text { Rf }\end{array}$ & $\begin{array}{l}\text { End } \\
\text { height }\end{array}$ & Area & $\begin{array}{l}\text { Area } \\
\text { \% }\end{array}$ & $\begin{array}{l}\text { Assigned } \\
\text { substance }\end{array}$ \\
\hline \hline 1 & 0.04 & 0.4 & 0.05 & 17.3 & 1.95 & 0.07 & 0.5 & 246.4 & 0.55 & unknown \\
2 & 0.12 & 3.5 & 0.16 & 31.2 & 7.565 & 0.18 & 24.0 & 919.5 & 8.53 & rutin \\
3 & 0.23 & 39.5 & 0.26 & 62.2 & 7.00 & 0.33 & 0.20 & 17360.7 & 5.27 & unknown \\
4 & 0.41 & 36.3 & 0.49 & 130.4 & 14.68 & 0.58 & 0.1 & 8069.1 & 18.02 & unknown \\
5 & 0.60 & 0.2 & 0.70 & 173.8 & 19.55 & 0.74 & 135.0 & 9714.4 & 21.70 & unknown \\
6 & 0.74 & 135.1 & 0.77 & 151.9 & 17.10 & 0.81 & 51.4 & 26261.8 & 13.99 & Gallic acid \\
7 & 0.82 & 51.6 & 0.87 & 197.1 & 22.18 & 0.91 & 115.8 & 19486.9 & 21.19 & Quercetin \\
\hline
\end{tabular}

\section{F. DPPH radical scavenging activity}

The free radical scavenging activity of the fractions was measured in vitro by 2,20- diphenyl-1-picrylhydrazyl (DPPH) assay according to the method described earlier12. A solution of $0.135 \mathrm{mM}$ DPPH in methanol was prepared and $1.0 \mathrm{ml}$ of this solution was mixed with 1.0 $\mathrm{ml}$ of extract in methanol containing $0.02-0.1 \mathrm{mg}$ of the extract. The reaction mixture left in the dark at room temperature for $30 \mathrm{~min}$. The absorbance of the mixture was measured spectrophotometrically at $517 \mathrm{~nm}$. Ascorbic acid was used as positive control. The ability to scavenge DPPH radical was calculated by the following equation:

DPPH radical scavenging activity $(\%)=[($ Abs Control Abssample)]/ (AbsControl)] x 100

where Abs control is the absorbance of DPPH radical + methanol; Abs sample is the absorbance of DPPH radical + sample extract /standard.

\section{G. Hydroxyl Radical Scavenging activity}

Hydroxyl radical scavenging activity of different fractions was evaluated by the method as previously described13. Hydroxyl radical is one of the potent reactive oxygen species in the biological system. It reacts with polyunsaturated fatty acid moieties of cell membrane phospholipids and causes damage to cell. The model used is ascorbic acid-iron- EDTA model of HO* generating system. This is a totally aqueous system in which ascorbic acid, iron and EDTA conspire with each other to generate hydroxyl radicals. The reaction mixture $(1.0 \mathrm{ml})$ consist of $100 \mu \mathrm{l}$ of 2-deoxy-Dribose $(28 \mathrm{mM}$ in $20 \mathrm{mM} \mathrm{KH}_{2} \mathrm{PO}_{4}-\mathrm{KOH}$ buffer, $\left.\mathrm{pH} 7.4\right), 500 \mu \mathrm{l}$ of the extract, $200 \mu$ I EDTA (1.04 mM) and $200 \mu \mathrm{M} \mathrm{FeCl}_{3}(1: 1$ $\mathrm{v} / \mathrm{v}), 100 \mu \mathrm{l}$ of $\mathrm{H}_{2} \mathrm{O}_{2}(1.0 \mathrm{mM})$ and $100 \mu \mathrm{l}$ ascorbic acid $(1.0 \mathrm{mM})$ which is incubated at $37^{\circ} \mathrm{C}$ for $1 \mathrm{~h} .1 .0 \mathrm{ml}$ of thiobarbituric acid $(1 \%)$ and $1.0 \mathrm{ml}$ of trichloroacetic acid $(2.8 \%)$ are added and incubated at $100^{\circ} \mathrm{C}$ for $20 \mathrm{~min}$. Reducing power is associated with antioxidant activity and may serve as a significant reflection of the antioxidant activity. Compounds with reducing power indicate that they are electron donors and can reduce the oxidized intermediates of lipid peroxidation processes, so that they can act as primary and secondary antioxidants. $1.0 \mathrm{ml}$ extract is mixed with $2.5 \mathrm{ml}$ of phosphate buffer (200 mM, pH 6.6) and $2.5 \mathrm{ml}$ of potassium ferricyanide $(30 \mathrm{mM})$ and incubated at $50^{\circ} \mathrm{C}$ for $20 \mathrm{~min}$. Thereafter, $2.5 \mathrm{ml}$ of trichloroacetic acid (600 $\mathrm{mM}$ ) is added to the reaction mixture, centrifuged for 10 $\min$ at $3000 \mathrm{rpm}$. The upper layer of solution $(2.5 \mathrm{ml})$ is mixed with $2.5 \mathrm{ml}$ of distilled water and $0.5 \mathrm{ml}$ of $\mathrm{FeCl}_{3}$ $(6 \mathrm{mM})$ and absorbance is measured at $532 \mathrm{~nm}$ against an appropriate blank solution. Ascorbic acid was used as positive control. 
European Journal of Advanced Chemistry Research www.ej-chem.org

TABLE 5: HPTLC PEAK TABLE FOR ETHYLACETATE FRACTION OF HAPN

\begin{tabular}{|c|c|c|c|c|c|c|c|c|c|c|}
\hline Peak & $\begin{array}{l}\text { Start } \\
\mathbf{R}_{\mathbf{f}}\end{array}$ & $\begin{array}{l}\text { Start } \\
\text { Height }\end{array}$ & $\begin{array}{l}\text { Max } \\
\mathbf{R}_{\mathrm{f}}\end{array}$ & $\begin{array}{l}\text { Max } \\
\text { height }\end{array}$ & $\begin{array}{l}\text { Max } \\
\%\end{array}$ & $\begin{array}{l}\text { End } \\
\text { Rif }\end{array}$ & $\begin{array}{l}\text { End } \\
\text { height }\end{array}$ & Area & Area \% & $\begin{array}{l}\text { Assigned } \\
\text { substance }\end{array}$ \\
\hline 1 & 0.11 & 0.2 & 0.17 & 57.3 & 9.01 & 0.19 & 50.5 & 2213.3 & 7.50 & Rutin \\
\hline 2 & 0.20 & 50.7 & 0.22 & 60.6 & 9.52 & 0.29 & 5.1 & 2651.9 & 8.99 & Unknown \\
\hline 3 & 0.35 & 12.2 & 0.38 & 34.0 & 5.35 & 0.39 & 17.6 & 619.8 & 2.10 & Unknown \\
\hline 4 & 0.48 & 10.9 & 0.51 & 21.2 & 3.32 & 0.56 & 4.1 & 812.6 & 2.75 & Unknown \\
\hline 5 & 0.63 & 2.7 & 0.76 & 234.3 & 36.82 & 0.80 & 40.6 & 13063.4 & 44.27 & Gallic acid \\
\hline 6 & 0.80 & 40.9 & 0.84 & 229.0 & 35.98 & 0.93 & 0.2 & 10145.8 & 34.38 & Unknown \\
\hline
\end{tabular}

TABLE 6: HPTLC PEAK TABLE FOR AQUEOUS FRACTION OF HAPN

\begin{tabular}{|c|c|c|c|c|c|c|c|c|c|c|}
\hline Peak & Start $R_{f}$ & $\begin{array}{l}\text { Start } \\
\text { Height }\end{array}$ & $\begin{array}{l}\text { Max } \\
\mathbf{R f}_{\mathbf{f}}\end{array}$ & $\begin{array}{l}\text { Max } \\
\text { height }\end{array}$ & $\begin{array}{l}\text { Max } \\
\%\end{array}$ & $\begin{array}{l}\text { End } \\
\text { Rf }\end{array}$ & $\begin{array}{l}\text { End } \\
\text { height }\end{array}$ & Area & Area \% & $\begin{array}{l}\text { Assigned } \\
\text { substance }\end{array}$ \\
\hline 1 & 0.03 & 0.4 & 0.04 & 11.8 & 1.15 & 0.55 & 0.0 & 90.3 & 0.16 & "Unknown \\
\hline 2 & 0.17 & 18.0 & 0.24 & 74.8 & 7.30 & 0.30 & 1.1 & 3748.8 & 6.46 & Unknown \\
\hline 3 & 0.30 & 1.1 & 0.31 & 13.3 & 1.30 & 0.32 & 1.8 & 70.7 & 0.12 & Unknown \\
\hline 4 & 0.33 & 4.0 & 0.36 & 33.6 & 3.27 & 0.38 & 28.0 & 855.1 & 1.47 & Unknown \\
\hline 5 & 0.42 & 35.2 & 0.44 & 47.0 & 4.59 & 0.45 & 44.2 & 908.0 & 1.56 & Unknown \\
\hline 6 & 0.45 & 44.3 & 0.49 & 74.0 & 7.21 & 0.57 & 1.3 & 3733.2 & 6.43 & Unknown \\
\hline 7 & 0.59 & 0.0 & 0.76 & 379.1 & 36.96 & 0.80 & 180.3 & 266686.7 & 45.98 & Gallic acid \\
\hline 8 & 0.80 & 181.1 & 0.84 & 392.0 & 38.22 & 0.93 & 3.0 & 21945.6 & 37.81 & Quercetin \\
\hline
\end{tabular}

TABLE 7: HPTLC PEAK TABLE FOR AQUEOUS FRACTION OF HAPN

\begin{tabular}{|c|c|c|c|c|c|c|c|c|c|c|}
\hline Peak & Start $R_{f}$ & $\begin{array}{l}\text { Start } \\
\text { Height }\end{array}$ & $\begin{array}{l}\text { Max } \\
\text { Rf }_{\mathbf{f}} \\
\end{array}$ & $\begin{array}{l}\text { Max } \\
\text { height }\end{array}$ & $\begin{array}{l}\text { Max } \\
\%\end{array}$ & $\begin{array}{l}\text { End } \\
\text { Rf }\end{array}$ & $\begin{array}{l}\text { End } \\
\text { height }\end{array}$ & Area & Area \% & $\begin{array}{l}\text { Assigned } \\
\text { substance }\end{array}$ \\
\hline 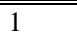 & 0.06 & 0.4 & 0.14 & 218.2 & 16.59 & 0.22 & 0.5 & 12213.4 & 20.43 & " Unknown \\
\hline 2 & 0.22 & 0.2 & 0.25 & 15.2 & 1.15 & 0.27 & 0.5 & 294.6 & 0.49 & Unknown \\
\hline 3 & 0.31 & 3.2 & 0.38 & 54.6 & 4.15 & 0.38 & 51.9 & 2020.9 & 3.38 & Unknown \\
\hline 4 & 0.43 & 68.3 & 0.48 & 104.0 & 7.91 & 0.57 & 1.9 & 6136.1 & 10.27 & Unknown \\
\hline 5 & 0.58 & 0.2 & 0.71 & 317.7 & 24.16 & 0.72 & 314.6 & 13518.4 & 22.62 & Unknown \\
\hline 6 & 0.72 & 315.2 & 0.76 & 357.5 & 27.19 & 0.81 & 63.9 & 15838.6 & 26.50 & Gallic acid \\
\hline 7 & 0.81 & 63.9 & 0.84 & 247.8 & 18.85 & 0.92 & 0.7 & 9745.5 & 16.31 & Quercetin \\
\hline
\end{tabular}

TABLE 8: PERCENTAGE INHIBITION OF HAPN AND ITS FRACTION ON DPPH RADICAL SCAVENGING ACTIVITY

\begin{tabular}{lllllll}
\hline Concentration & Standard & Hydroalcoholic & Pet ether & $\begin{array}{l}\text { Ethyl } \\
\text { acetate }\end{array}$ & n-Butanol & Aqueous \\
\hline \hline 20 & 85.82 & 84.92 & 53.07 & 95.41 & 91.20 & 88.28 \\
40 & 87.04 & 85.70 & 55.14 & 96.12 & 91.86 & 90.22 \\
60 & 87.89 & 90.02 & 57.29 & 96.49 & 94.50 & 91.08 \\
80 & 92.26 & 93.64 & 66.30 & 96.84 & 95.94 & 93.76 \\
100 & 94.95 & 93.80 & 66.89 & 97.03 & 96.51 & 94.53 \\
& & & & & & \\
\hline
\end{tabular}

TABLE 9: PERCENTAGE INHIBITION OF HAPN AND ITS FRACTION ON HYDROXYL

RADICAL SCAVENGING ACTIVITY

\begin{tabular}{lllllll}
\hline Concentration & Standard & Hydroalcoholic & $\begin{array}{l}\text { Pet } \\
\text { ether }\end{array}$ & $\begin{array}{l}\text { Ethyl } \\
\text { acetate }\end{array}$ & n-Butanol & Aqueous \\
\hline \hline 20 & 74.82 & 64.51 & 15.3 & 72.96 & 73.38 & 62.51 \\
40 & 77.04 & 64.97 & 18.56 & 76.29 & 74.43 & 62.82 \\
60 & 77.89 & 69.12 & 18.73 & 78.90 & 78.35 & 69.20 \\
80 & 81.20 & 71.56 & 24.14 & 84.67 & 84.47 & 72.05 \\
100 & 83.67 & 71.76 & 37.03 & 87.45 & 85.62 & 73.61 \\
& & & & & & \\
\hline
\end{tabular}


TABLE 10: PERCENTAGE INHIBITION OF HAPN AND ITS FRACTION ON REDUCING POWER

\begin{tabular}{lllllll}
\hline Concentration & Standard & hydroalcoholic & $\begin{array}{l}\text { Pet } \\
\text { ether }\end{array}$ & $\begin{array}{l}\text { Ethyl } \\
\text { acetate }\end{array}$ & n-Butanol & Aqueous \\
\hline \hline 20 & 0.207 & 0.080 & 0.012 & 0.198 & 0.178 & 0.110 \\
40 & 0.210 & 0.085 & 0.028 & 0.214 & 0.210 & 0.118 \\
60 & 0.329 & 0.135 & 0.044 & 0.344 & 0.301 & 0.144 \\
80 & 0.385 & 0.170 & 0.051 & 0.402 & 0.398 & 0.207 \\
100 & 0.486 & 0.210 & 0.051 & 0.490 & 0.420 & 0.263 \\
& & & & & & \\
\hline
\end{tabular}

\section{H.Reducing power antioxidant activity}

The reducing power was determined as described as earlier14. Reducing power is associated with antioxidant activity and may serve as an important indicator of the antioxidant activity. Compounds with reducing power indicate that they are electron donors and can reduce the oxidized intermediates of lipid peroxidation processes, so that they can act as primary and secondary antioxidants. $1.0 \mathrm{ml}$ extract is mixed with $2.5 \mathrm{ml}$ of phosphate buffer $(200 \mathrm{mM}, \mathrm{pH}$ 6.6) and $2.5 \mathrm{ml}$ of potassium ferricyanide $(30 \mathrm{mM})$ and incubated at $50^{\circ} \mathrm{C}$ for $20 \mathrm{~min}$. Thereafter, $2.5 \mathrm{ml}$ of trichloroacetic acid $(600$ $\mathrm{mM}$ ) is added to the reaction mixture, centrifuged for 10 $\mathrm{min}$ at $3000 \mathrm{rpm}$. The upper layer of solution $(2.5 \mathrm{ml})$ is mixed with $2.5 \mathrm{ml}$ of distilled water and $0.5 \mathrm{ml}$ of $\mathrm{FeCl} 3$ $(6 \mathrm{mM})$ and absorbance is measured at $700 \mathrm{~nm}$. Ascorbic acid was used as positive control.

\section{RESULTS AND DISCUSSION}

The amount of materials that can be extracted from a plant depends on the vigour of the extraction procedure and the possibility also exists of sample-to-sample variation in the extracted material. The crude HAPN yield of all plant parts varied from $40.12 \% \mathrm{~W} / \mathrm{W}$ dry raw materials. The percentage yield of various fractions from HAPN, were summarized in Table 1. This result is in line with a work conducted earlier15, which performed Soxhlet extraction using organic and aqueous solvents to obtain various crude extracts from Phyllanthus niruri L. The authors reported that the yield was high when using water and polar solvents (ethanol and methanol), however the yield was significantly decreased with non-polar solvents (hexane and petroleum ether). Preliminary phytochemical screening showed the presence of flavonoids, terpenes, coumarins, lignans, tannins, carbohydrates and alkaloids. However, steroid and terpenoids are not identified. The results are summarized in Table 2. As previous study 16 reported that, from thin layer chromatography (TLC) and HPLC analysis, P. niruri L aerial extracts showed a positive result for the presence of phenols, flavonoids, tannins, saponin, steroids, and lipids. The results from the phytochemical tests differ from other studies due to at least three possible factors such as geographical location, extraction procedure and sensitivity of the techniques. Presence of hydroxyl group in the plant phenolic compounds plays a vital role for antioxidant property with free radical neutralizing activity 17 . This is due to their redox properties, which play an important role in adsorbing and neutralising free radicals, quenching singlet or triplet oxygen and decomposing peroxides. Total phenolic content of various fraction of HAPN were determined using Folin-Ciocalteu reagent. Total phenolic content of the sample was calculated based on the standard curve for gallic acid and the results were expressed as $\mathrm{mg}$ of gallic acid equivalent (GAE)/g of dried extractives and was tabulated in Table 3. The phenolic content of ethyl acetate fraction from HAPN is higher in amount than petroleum ether fraction. Various clinical studies confirmed the prolonged use of polyphenol enriched diet can prevent many chronic diseases including $\mathrm{AD}$ 18. Plants with higher biologically active polyphenols act as neuroprotective agents which shows significant protection against neural injuries and degeneration. As a subclass of this family, flavonoids act as a potent antioxidant, anti-inflammatory and signalling pathways modulatory agents. Flavonoids are considered as well-known antioxidants due to their radical scavenging, metal ion chelating and lipid peroxidation inhibiting activities. AD occur mainly due to oxidative stress. Flavonoids may prevent or slower the progression of $\mathrm{AD}$ that are act by inhibiting the enzymes such as $\beta$-secretases, cyclin dependent kinase and glycogen synthase which are playing key role in phosphorylation of tau proteins. Flavonoids takes part in neural rehabilitation and lost cognitive performance recovery which are considered as potent anti-AD effects 19,20. In our study total flavonoids content was determined by aluminium chloride colorimetric method. Flavonoid content of the samples was calculated based on the standard curve for quercetin and the results were expressed as $\mathrm{mg}$ of quercetin equivalent (QE)/g of dried extractives and was tabulated in Table 3. The flavonoid content of ethyl acetate fraction from HAPN was estimated as $73.12 \pm 1.07 \mathrm{mg}$ of $\mathrm{QE} / \mathrm{g}$ of dried extract which is very high in comparison with the flavonoid content of other fractions.

The various fraction of HAPN having the potentiality to scavenge the free radical contains flavonoids which was analysed by using HPTLC. The peak table, peak display and peak densitogram were noted. Thus, the presence of flavonoids and phenolic compound in the various fraction of HAPN was confirmed by HPTLC analysis and were shown in Table 4-7 and Figure 1\&2. It was observed that the aqueous fraction showed the presence of quercetin, ethyl acetate fraction contained rutin, n-Butanol fraction contains quercetin and all the fractions contained gallic 
acid. They were confirmed from the chromatogram after derivatization as in Figure 3. Calixto, et al., reported that P. niruri contained flavonoids quercetin, quercitrin, isoquercitrin, astragalin, rutin and physetinglucoside 21. Mediani, et al22., reported that it contained a high amount of rutin, followed by gallic acid, quercetin.

Many studies have focused on the biological activities of phenolics which are potent antioxidants and free radical scavengers. The antioxidant activity of phenolics is mainly due to their redox properties, which allows them to act as reducing agents, hydrogen donors, and singlet oxygen quenchers. The interest in phenolic compounds derived from vegetables and their roles in nutrition are therefore increasing. Phenolic compounds are also known to play an important role in stabilizing lipids against peroxidation and inhibiting various types of oxidizing enzymes. The differences in the flavonoid structures and their substitutions influence the phenoxyl radical stability, thereby affecting the antioxidant properties of the flavonoid 23. Enzymatic antioxidants such as superoxide dismutase (SOD), catalase (CAT), glutathione peroxidase $(\mathrm{GPx})$, etc and non-enzymatic antioxidants such as carotenoids, ascorbic acid, phenolic compounds, flavonoids, etc act by one or more mechanisms like reducing activity, free radical scavenging, potential complexing of pro-oxidant metals and quenching of singlet oxygen. It is possible to reduce the risks of chronic diseases and prevent the disease progression by either enhancing the body's natural antioxidant defense or supplementing with proven antioxidants.

When a solution of DPPH is mixed with that of a substance that can donate a hydrogen atom, then this gives rise to the reduced form with the loss of this violet color (although there would be expected to be a residual paleyellow color from the picryl group still present). The degree of color change is proportional to the concentration and potency of the antioxidants. A huge decrease in the absorbance indicates significant free radical scavenging activity of the extract under test 24 . The results were expressed as ascorbic acid (AA) equivalents (AAE/g) and shown in Table 8 . Our findings indicate that $20 \mu \mathrm{g} / \mathrm{mL}$ of the fractions were found to be in the order ethyl acetate > n-butanol > aqueous > HAPN > pet ether (97.03\%) and ascorbic acid conferred $96.82 \%$ on DPPH radicals. The logic behind this behaviour may be explained by the presence of phytoconstituents that are capable of donating hydrogen or electron to a free radical to scavenge the potential damage by them. These results suggest that fractions have high radical scavenging activity. Radical scavenging activities are very important to prevent the deleterious role of free radicals in AD.

Hydroxyl radical is one of the potent reactive oxygen species in the biological system. It reacts with polyunsaturated fatty acid moieties of cell membrane phospholipids and causes damage to cell. Table 9 showed the hydroxyl radical scavenging activity of various fraction of HAPN and compared with ascorbic acid. It was observed that ethyl acetate and n-butanol fraction had higher activity compared to ascorbic acid. The molecular mechanisms underlying the pathogenesis of cell death in neurodegenerative or amyloid diseases, could be the direct production of hydrogen peroxide during formation of the abnormal protein aggregates $\mathrm{A}$ (beta) and alpha-synuclein by a metal-dependent mechanism in which addition of $\mathrm{Fe}$ (II), by Fenton's reaction. Hydrogen peroxide subsequently converted to hydroxyl radicals. 25,26. From the above finding our HAPN fractions can be used to nullify the deleterious effects of hydroxyl radicals in various disease processes.

The reducing capacity of a compound is the potent indicator of its antioxidant activity. The reducing properties are generally associated with the presence of reductones, which have been shown to exhibit antioxidant action by breaking the free radical chain by donating a hydrogen atom and may have great relevance in the prevention and treatment of diseases associated with oxidants or free radicals27.All fractions of our study showed reducing activity compared to ascorbic acid which was a reference antioxidant and was summarized in Table 10. The ethyl acetate fraction showed increased reducing activity with the increasing concentration of the extract compared to other fractions and standard drug.

As our results, indicating that the ethyl acetate fractions showed greater antioxidant activity due to the presence of higher amount of phenolic and flavonoid contents. The previous studies 28,29 suggested that methanol extract had a better TPC and DPPH activity when compared to water extract based on their polarity. We believed that the greater antioxidant property of ethyl acetate fractions might be by less polarity. Plant antioxidant activity, however, also depends on other non-polyphenolic compound such as vitamins, minerals and carotenoids. These nonpolyphenolic compounds may exert synergistic effect with TPC and TFC, which could further enhance the antioxidants activities. Further studies are needed to identify which phenolic compounds are responsible for the antioxidant activity of the species and assess the way in which the phenolic substances contribute to this activity.

\section{CONCLUSION}

In conclusion, the present study provides the evidence that the HAPN and fractions obtained from HAPN contains flavonoid and phenolic contents. They show potential antioxidant and free radical scavenging activity. These In-vitro assays demonstrate that this ethyl acetate fraction is an important source of natural antioxidant and can be used for preventive and therapeutic purpose for diseases caused by oxidative stress and free radicals.

\section{REFERENCES}

[1] M. Moniruzzaman, M. Asaduzzaman, Sarwar Hossain, S. Jyotirmoy, and S.M. Abdur Rahman, "In vitro antioxidant and cholinesterase inhibitory activities of methanolic fruit extract of Phyllanthus acidus,".BMC Complement Altern Med, ,vol. 15,pp. 403, 2015.

[2] S. H. Nile, and S. W. Park, "HPTLC Analysis, Antioxidant and Antigout Activity of Indian Plants," Iran J Pharm Res, ,vol. 13, no. 2, pp. 531-539, 2014.

[3] P.S. Tresina, S. M.J. Kala,and V.R. Mohan, "HPTLC fingerprint analysis of phytocompounds and in vitro antioxidant activity of 
Eugenia singampattiana Bedd," J Appl Pharm Sci, vol. 2, no.12, pp. 112-124, 2012.

[4] N. Giribabu, Pasupuleti Visweswara Rao, K. Praveen Kumar, S. Muniandy, S. Swapna Rekha, and Naguib Salleh, "Aqueous Extract of Phyllanthus niruri Leaves Displays In Vitro Antioxidant Activity and Prevents the Elevation of Oxidative Stress in the Kidney of Streptozotocin-Induced Diabetic Male Rats," Evid Based Complement Alternat Med, 834815, 2014.

[5] R. Mostofa, Shanta Ahmed, M. M. Begum, S. Rahman, T. Begum,and S.U. Ahmed, "Evaluation of anti-inflammatory and gastric anti-ulcer activity of Phyllanthus niruri L. (Euphorbiaceae) leaves in experimental rats," BMC Complement Altern Med, vol. 17 , pp. $267,2017$.

[6] M. Ayaz, M .Junaid, M .Ahmed, F .Ullah, A. Sadiq, S .Ahmad, and Imran, "Phenolic contents, antioxidant and anticholinesterase potentials of crude extract, subsequent fractions and crude saponins from Polygonum hydropiper L," BMC Complement Altern Med, vol. 14, pp.145, 2014.

[7] Y.H. Koay, A. Basiri, V. Murugaiyah, and K.L. Chan, "Isocorilagin, a Cholinesterase Inhibitor from Phyllanthus niruri," Nat Prod Commun, vol.9, no.4, pp.515-517, 2014.

[8] H.M Amzad,and R .Mizanur, "Isolation and characterisation of flavonoids from the leaves of medicinal plant Orthosiphon stamineus." Arab J Chem, vol.8, pp. 218-221, 2015.

[9] W.C. Evans. Trease and evans pharmacognosy. 15th ed, Sanders, London; 2008.

[10] N. Saeed, R. K. Muhammad,and M. Shabbir, "Antioxidant activity, total phenolic and total flavonoid contents of whole plant extracts Torilis leptophylla L," BMC Complement Altern Med, vol.12, pp. 221,2012.

[11] J. Zhishen, T. Mengcheng, and W.Jianming, "The determination of flavonoid contents in mulberry and their scavenging effect on superoxide radicals," Food Chem, vol.64, pp.555-559, 1999.

[12] X. Liu, J. Lei Yang, F. Yang, G. Hongshuang, and C. Zhao, "Evaluation of Antioxidant Activities of Aqueous Extracts and Fractionation of Different Parts of Elsholtzia ciliate," MDPI, vol. 17, pp. 5430-5441, 2012.

[13] B.Hazra,and S. Nripendranath Mandal, "Antioxidant and free radical scavenging activity of Spondias pinnata," $B M C$ Complement Altern Med, vol.8, no.63,pp.1-10, 2008.

[14] E. Bursal,and İ. Gülçin, "Polyphenol contents and in vitro antioxidant activities of lyophilised aqueous extract of kiwifruit (Actinidia deliciosa)," Food Res Int, vol.44, pp.1482-1489, 2011.

[15] M. Markom, M.Hasan, W.R. Daud, H. Singh,and J.M. Jahim, "Extraction of hydrolysable tannins from Phyllanthus niruri Linn.: Effects of solvents and extraction methods," Sep Purif Technol, vol. 52, pp. 487-496, 2007.

[16] R.K. Nakweti, S.L. Ndiku, P. Doumas, H.S. Nkung, Y. Baissac, R.C. Kanyanga,.and A.D. Ndofunsu, "Phytochemical analysis of Phyllanthus niruri L. (Phyllanthaceae) extracts collected in four geographical areas in the Democratic Republic of the Congo," Afr J Plant Sci,vol.7,pp.9-20, 2013.

[17] S. N. Dalila Mohd Zain, and W. A. Wan Omar, "Antioxidant Activity, Total Phenolic Content and Total Flavonoid Content of Water and Methanol Extracts of Phyllanthus species from Malaysia,”. Pharmacogn J, vol.10,no.4,pp.677-681, 2018.

[18] H. Cory, S. Passarelli, J. Szeto, M. Tamez, and J. Mattei, "The Role of Polyphenols in Human Health and Food Systems: A MiniReview." Front. $\quad$ Nutr, 2018. https://doi.org/10.3389/fnut.2018.00087.

[19] M .Bakhtiari, Y.Panahi, J. Ameli, and B. Darvishi, "Protective effects of flavonoids against Alzheimer's disease-related neural dysfunctions," Biomed Pharmacother, vol.93, pp.218-229, 2017.

[20] Y. Kumarasamy, M. Byres, P.J. Cox, and S.D. Sarkar, "Screening seeds of some Scottish plants for free radical scavenging activity," Phytothe Res, vol.21,pp.615-621, 2007.
[21] D. Rusmana, R Wahyudianingsih, M.Elisabeth, Balqis, Maesaroh, and Wahyu Widowati, "Antioxidant Activity of Phyllanthus niruri Extract, Rutin and Quercetin," Indones Biomed J, vol. 9, no.2, pp. 84-90, 2017.

[22] A .Mediani, F .Abas, A .Khatib, C.P. Tan, I.S. Ismail, andK .Shaari, "Phytochemical and biological features of Phyllanthus niruri and Phyllanthus urinaria harvested at different growth stages revealed by $1 \mathrm{H}$ NMR-based metabolomics," Ind Crops and Prod, vol.77, pp. 602-613, 2015.

[23] S.Chandra, S. Khan, Bharathi Avula,,Hemant Lata, and Min Hye Yang, "Assessment of Total Phenolic and Flavonoid Content, Antioxidant Properties, and Yield of Aeroponically and Conventionally Grown Leafy Vegetables and Fruit Crops: A Comparative Study," Evid Based Complementary Altern Med, pp.1-9, 2014.

[24] C.Sarikurkcu, K.Arisoy, B .Tepe, A .Cakir, G .Abali, and E. Mete, "Studies on the antioxidant activity of essential oil and different solvent extracts of Vitex agnus castus L. fruits from Turkey," Food Chem Toxicol, vol.47,no.10,pp.279-283, 2009.

[25] Wen-Juan Huang, Xia Zhang, and Wei-Wei Chen, "Role of oxidative stress in Alzheimer's disease," Biomed Rep. vol.4,no.5, pp 519-522, 2016.

[26] Boguslaw Lipinski. "Hydroxyl radical and its scavengers in health and disease," Oxid Med Cell Longev , Article ID 809696, 9 pages. 2011.

[27] Ishrat Nimmi, Ismet Ara Jahan, Hemayet HossainM, Mohammad Burhan Uddin, Sohel Rana M, and Muhammad Mahbubul Haq, "A Comparative Study on Antioxidant Properties of Two Phyllanthus Species Growing in Bangladesh, Dhaka," Univ J Pharm Sci, vol.11,no.2,pp.191-197,2012.

[28] Y.K. Cheah, and S. Radu, "Bioprotective properties of three Malaysia Phyllanthus species: An investigation of the antioxidant and antimicrobial activities," Int Food Res J. vol.18,no.3,pp.887893, 2011.

[29] Siti Nur Dalila Mohd Zain,and Wan Adnan Wan Omar, "Antioxidant Activity, Total Phenolic Content and Total Flavonoid Content of Water and Methanol Extracts of Phyllanthus species from Malaysia," Pharmacogn J, vol.10,no.4,pp.677-681, 2018. 


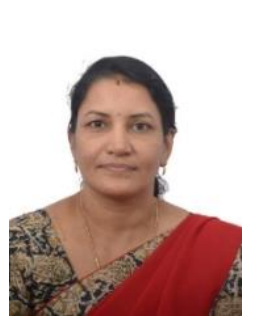

Manju S.L is working as associate professor, Department of chemistry in School of advanced sciences, Vellore institute of technology, Vellore.

She is having vast number of national and international publications. She is guiding number of Ph.D students, Masters and bachelor degree students.

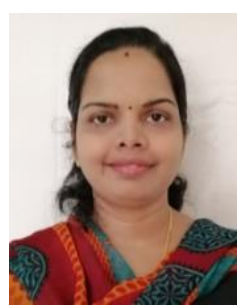

Gayathri Rajamanickam qualified Master of Pharmacy in Pharmaceutical chemistry, J.S.S. University, Mysore, India on March 2010.

Gayathri has 12 years of experiences in teaching and research. Having 15publications including national and international journals and currently pursuing Ph.D. in Vellore institute of technology, Vellore, India.

Gayathri had received St. Peter institute of Pharmaceutical Sciences Gold medal for securing highest marks in the Pharm in JSS University and Qualified in All India Council for Technical Education (AICTE) Sponsorship cum stipend for M. Pharm course. 